RESEARCH PAPER

\title{
British Columbia capital regional district 100\% smokefree bylaw: a successful public health campaign despite industry opposition
}

\section{J Drope, S Glantz}

See end of article for authors' affiliations

\section{Correspondence to:} Professor Stanton Glantz, University of California, San Francisco, Center for Tobacco Control Research and Education, 530 Parnassus Avenue, Room 366, San Francisco, CA 94143-1390, USA glantz@medicine.ucsf.edu

Received 12 September 2002

Accepted 24 April 2003
Objective: To describe how the British Columbia Capital Regional District successfully passed, implemented, and enforced a 100\% smokefree bylaw in all public places, including restaurants and bars, despite an aggressive campaign by the tobacco industry (acting through the hospitality industry) to stop it.

Methods: Information was obtained from news reports, internal tobacco industry documents, reports, public documents, and interviews with key players. Tobacco industry documents were accessed between February and April 2002. This project was approved by the University of California San Francisco committee on human research.

Results: As in the USA and elsewhere in the world, the tobacco industry in British Columbia, Canada, recruited and created hospitality associations to fight against the district smokefree bylaw. They used the classic industry rhetoric of individual rights and freedoms, economic devastation, and ventilation as a solution. Public health authorities were able to counter industry strategies with a strong education campaign, well written bylaws, and persistent enforcement.

Conclusion: It is possible to overcome serious opposition orchestrated by the tobacco industry and develop and implement a 100\% smokefree bylaw in Canada. Doing so requires attention to detail in drafting the bylaw, as well as a public education campaign on the health dangers of secondhand smoke and active enforcement to overcome organised resistance to the bylaw. Jurisdictions considering smokefree bylaws should anticipate this opposition when developing and implementing their bylaws.
1 $\mathrm{n}$ the mid 1970s, jurisdictions in the USA began enacting restrictions on smoking in workplaces and public places ${ }^{1}$ despite opposition from the tobacco industry. The industry opposes these restrictions because they reduce the social acceptability of smoking ${ }^{2}$ and make it easier for smokers to reduce or stop smoking. ${ }^{4}$ While this situation provides clear health benefits for the public, it costs the tobacco industry lost sales and profits, so the industry mounts major efforts, ${ }^{15-10}$ often through the hospitality industry, ${ }^{11}{ }^{12}$ to oppose these laws. In Canada, the Capital Regional District of British Columbia was the first region in the country to successfully pass, implement, and enforce a $100 \%$ smokefree bylaw that includes all restaurants and bars. The area has a 20 year history of developing bylaws controlling secondhand smoke (SHS) (table 1). This paper describes: the development and implementation of the bylaw; how opponents mobilised against it (an effort secretly orchestrated by the Canadian tobacco industry and its foreign owners); how public health authorities adapted to and overcame this opposition; and ultimately how the regional government successfully enacted and implemented a bylaw making all public places including restaurants, bars, casinos, and bingo halls smokefree. This success was due to a systematic, organised educational campaign, a series of bylaws that were strong and clearly written, recognition of tobacco industry tactics and a plan to counter them, and strong and persistent enforcement of the bylaws.

\section{METHODS}

We obtained information from news reports, internal tobacco industry documents made available as a result of litigation in the USA, reports, public documents, and recorded and transcribed interviews with key players (conducted in August 2001) after obtaining informed consent. We selected interviewees based on the written record and the snowball technique. This project was approved by the University of California San Francisco committee on human research.

Table 1 Requirements of smoking restriction bylaws in the Capital Regional District of British Columbia (percentage of smokefree space)

\begin{tabular}{|c|c|c|c|c|c|c|}
\hline Year & Workplaces & $\begin{array}{l}\text { Retail stores and public } \\
\text { premises }\end{array}$ & $\begin{array}{l}\text { Restaurants and } \\
\text { licensed premises }\end{array}$ & $\begin{array}{l}\text { Bingo } \\
\text { halls }\end{array}$ & $\begin{array}{l}\text { Extended and long term } \\
\text { care facilities }\end{array}$ & $\begin{array}{l}\text { Bowling } \\
\text { alleys }\end{array}$ \\
\hline 1984 & & Non-smoking areas & $25 \%$ & & & \\
\hline 1986 & Designated non-smoking areas & Designated non-smoking areas & & & & \\
\hline 1991 & & & $50 \%$ & $25 \%$ & $100 \% *$ & $50 \%$ \\
\hline 1992 & $100 \%$ * & & & $30 \%$ & & \\
\hline 1993 & & & & $35 \%$ & & \\
\hline 1994 & & & $60 \%$ & $40 \%$ & & \\
\hline 1999 & $100 \%$ & $100 \%$ & $100 \%$ & $100 \%$ & $100 \%$ & $100 \%$ \\
\hline
\end{tabular}

*Separately ventilated designated smoking area permitted. Percentages were obtained from bylaws enacted each year. 


\section{RESULTS}

\section{Development and passage of the bylaw}

As early as 1993, the district medical health officer, Shawn Peck, proposed a smokefree region. The proposal was quickly abandoned after vehement objection from the regional Food and Restaurant Association. For the next two years, Peck and his staff continued to promote $100 \%$ smokefree places in the media and in public by publishing a brochure of almost 100 restaurants (out of approximately 1000 in the region) that had gone smokefree voluntarily. ${ }^{13}$

In 1995, armed with mounting evidence that SHS was dangerous, Peck recommended to the district board and its health committee that the regional Clean Air Bylaw be amended to make all indoor spaces $100 \%$ smokefree, commencing January 1998. ${ }^{13}$ Shortly after, Richard Stanwick took over the position and proposed the bylaw be enacted by 1996 but opposition quickly convinced the board's health committee of the need for more consultation.

Meanwhile, a similar debate ensued in Vancouver, British Columbia's largest city. Since it was believed that Vancouver would become the first city to adopt a smokefree bylaw including restaurants and bars, tobacco industry opposition became strong and focused there. When the district began holding meetings, opponents of the bylaws in Vancouver and the district worked together. One of the key opponents in both places was Bruce Clark, a Vancouver pub owner who represented the newly formed, tobacco industry funded Lower Mainland Hospitality Group. ${ }^{14}$ Following standard tobacco industry rhetoric, ${ }^{11}{ }^{12}$ Clark claimed economic devastation would follow a smokefree bylaw, with the hospitality business falling by $15-50 \% .{ }^{15}$ Clark's coalition hired CCG Consulting Group of Vancouver, which estimated that requiring smokefree restaurants would cost 2700 jobs there. ${ }^{16}$ The tobacco industry did not make any direct appearances in the public debates.

After the district health committee requested further consultation, Stanwick and his staff met with representatives from Victoria's licensed liquor serving establishments. The only solution many of the hospitality representatives were willing to accept was the tobacco industry's "accommodation solution"11 in which smoking would continue to be permitted with special ventilation or separate smoking rooms. ${ }^{13}$

To explore whether the proposed ventilation solution would protect health, Stanwick's office hired a Victoria consulting engineer to estimate the level of ventilation necessary to provide health protection from the toxins in SHS. The engineer estimated that the number of air changes per hour needed to protect the health of people where smoking was permitted would be the equivalent of sitting in a $20 \mathrm{~km} / \mathrm{h}$ wind tunnel, and that there was no viable health based ventilation solution. ${ }^{17}$ With this research and the mounting scientific evidence that there was no safe level of SHS exposure, Stanwick refused to agree to any ventilation solution. ${ }^{18}$

When it was clear an agreement would not be reached, the meetings broke down and the health committee requested public hearings. Ten hours of hearings were coordinated and broadcasted live on local radio. More than 90 people spoke, many of whom had opposed the bylaw in Vancouver. ${ }^{19}$

A poll commissioned by Stanwick's office showed 61\% of the population supported a $100 \%$ smokefree bylaw. ${ }^{20}$ With this support, Stanwick decided that January 1998 would be a reasonable implementation date, the same date planned for Vancouver. The regional chapter of the Food and Restaurant Association agreed restaurants could go smokefree but argued the date should be delayed until 2000. The head of the association, Don Monsour, wanted all establishments to go smokefree at the same time because he feared a loss of business if restaurants, but not bars, were required to go smokefree. British Columbia liquor laws require that restaurants serve alcohol only if the patron intends to eat, whereas bars can serve alcohol with or without food. Since all the pubs in the region served food, Monsour feared people would simply change venues in order to smoke which would devastate small restaurants. He was also concerned about smoking rooms and other ventilation solutions the pub owners were advocating because capital and operating costs were prohibitive for most restaurants, and ventilation standards could change over time. ${ }^{21}$

Despite opposition, the health committee unanimously recommended all public places go smokefree on 1 January 1998. At the full district board meeting, a compromise was proposed that delayed implementation a year. Monsour agreed to the compromise and ensured full cooperation from the restaurants as long as bars went smokefree at the same time. ${ }^{18}$ In response, the board enacted a bylaw that required all public places to go smokefree by 1 January 1999.

Meanwhile, in Vancouver, intense lobbying from the hospitality industry defeated the bar provisions of its proposed bylaw. Their new bylaw required all restaurants to go smokefree, but excluded bars and pubs. ${ }^{22}$ The district was suddenly the first municipal jurisdiction in Canada to go 100\% smokefree in all public spaces.

\section{Preparation for implementation}

By 1998, local opponents began to organise to pressure regional politicians and health authorities to rescind the law. (The tobacco industry played no public role in the opposition.) Don Rittaler, a bar owner, began a court challenge of the bylaw based on its constitutionality. His court documents and media statements repeated classic tobacco industry arguments of personal rights and freedoms, ventilation as a solution, and the dire economic consequences of a smokefree bylaw. ${ }^{82}$ The industry offered assistance to Rittaler in presenting his case in the media, ${ }^{24}$ but he never brought the case to court. ${ }^{25}$ At the end of 1998 the district faced a new challenge when the provincial Workers' Compensation Board announced it was going to introduce regulations that would protect workers from SHS in all workplaces in British Columbia. Opponents of the district bylaw suggested that the district board wait to see what would happen but the board announced that the regulations would not come into effect until I January 2000, one year after the district's bylaw. Workers' Compensation Board representatives explained that their regulations were intended to complement and not replace local bylaws. The board regulation was weaker than the district bylaw because it allowed smoking rooms. ${ }^{26}$

Meanwhile, a group whose publicly disclosed membership consisted primarily of owners of bars and pubs created the Victoria Age of Majority Business Coalition to prevent the bylaw from coming into effect. They pursued an aggressive public relations campaign communicating their message through radio, print advertising, bumper stickers, and public information sessions. They emphasised the tobacco industry's messages of freedom of choice, ventilation solutions, and job loss in the hospitality sector. They also argued that the pending Workers' Compensation Board regulation made the district bylaw unnecessary and too restrictive. ${ }^{27-30}$

Also that year, representatives from the newly organised Capital Health Region (CHR) and Monsour travelled to California to observe the state's smokefree bar law, which had been in place since January of that year. Monsour, who had been reluctant to go, was surprised by how well the California law was working. This recognition fostered a relationship of openness and trust between Monsour and the CHR. ${ }^{13}{ }^{21}$ The group also invited two bar owners from California to Victoria to refute claims that a smokefree bylaw would adversely affect the hospitality and tourism industries. ${ }^{31}$

\section{Implementation and enforcement}

The CHR created a comprehensive communications strategy to ensure that everyone, especially those directly affected, understood the bylaw. Health officials sent an information kit to all 
hospitality establishments that contained a copy of the bylaw, suggestions to employees on how to deal with customers, information on the health effects of SHS and smoking cessation programmes, sample coasters, and signs prohibiting smoking. ${ }^{30}$

The CHR set up telephone lines for the general public to call with complaints and publicised on signs in bars and in ads that were run every two days in the Victoria Times-Colonist and the News Group for a year. ${ }^{13}$ The bylaw put the onus on the individual smoker and the enforcement plan was to issue citations to those found smoking. For the first few weeks environmental health officers were redeployed from other duties to help a tobacco enforcement team respond to complaints and conduct routine inspections. ${ }^{13}$

A minority of bar owners refused to cooperate and openly defied the law. Brian Mayzes, the main spokesperson of the Age of Majority Coalition, managed one of the most defiant pubs. He posted signs throughout his bar to tell patrons it was a smoking establishment and made many media appearances to state smoking was the choice of his customers. ${ }^{32}$ The level of hostility was so high that the police had to be called in as back up enforcement. Tickets did not deter him. Mayzes told reporters that he would not ensure the safety of health and bylaw officers if they tried to enforce the law. His customers greeted officers with Nazi slogans and salutes. ${ }^{33}$ Similar occurrences happened in a few other bars. ${ }^{34}$

In the 1999 mayoral election Mayzes made the bylaw a political issue by running against the incumbent Frank Leonard, who championed the bylaw in the district. Leonard won by a landslide. ${ }^{35}$

The CHR staff had not anticipated the hostility they would face, so replaced the original system of health inspectors visiting alone with one in which they were accompanied by regional bylaw officers, with the proper training for such situations ${ }^{34}$ until 2001, when the problems receded.

During the lead up to implementation and the first few weeks after, Stanwick was available to all media 24 hours a day, seven days a week to answer questions and counter false information being spread by opponents from the hospitality industry. ${ }^{36}{ }^{37}$ The media reported on the 50 defiant bars rather than the 1250 complying establishments, giving the impression of widespread non-compliance. Reporters focused on the contentiousness of the legislation and the possibility of violence.

Enforcement personnel soon realised that the system of ticketing individual smokers was not working. The onus needed to be on the operators and owners. ${ }^{13}$ A Vancouver court decision, which ruled that it was not unreasonable to have owners prevent smoking on their premises, encouraged the board to modify the bylaw to cite operators and owners in addition to smokers. ${ }^{38}$

Modifying the enforcement mechanism in the bylaw provided another opportunity for members of the Freedom of Choice Coalition (the former Age of Majority Coalition) to voice their fierce opposition. ${ }^{39}$ Despite intense pressure, in 1999 the district voted to amend the bylaw. Enforcement officers could now cite owners as well as individual smokers.

\section{The improved bylaw}

The enforcement change quickly reduced the number of noncompliant bars from 50 to 30 . CHR staff recognised that more stringent measures would be needed for the remaining bars and their owners, who simply treated $\$ 100$ (Canadian) fines as a cost of doing business. The CHR staff decided to use civil injunctions against any businesses which repeatedly defied the bylaw, as being found guilty in court would result in much more severe penalties. ${ }^{40}$

After the CHR decided the injunctive route was the best solution, they served legal papers on the six worst offending bars. Only one bar risked being held in contempt of court. The process of obtaining evidence lasted over a year, but when the case was heard, the district's lawyer requested a \$75 000 fine. The threat of such a high penalty prompted the bar to agree to obey the bylaw and pay a $\$ 15000$ penalty. ${ }^{41}$ The number of bars defying the law dwindled rapidly.

During this time the Worker's Compensation Board regulations also went into effect. This took some pressure off district enforcement personnel because Workers' Compensation Board fines ranged from $\$ 1500$ to $\$ 4000^{42}$ compared to the $\$ 100$ fines under the bylaw. In January 2000, however, the British Columbia Liquor Licensee and Retailers Association, an organisation with tobacco ties, ${ }^{43-45}$ filed a petition in the British Columbia Supreme Court, claiming the board had not followed the proper procedure of public hearings before it ended smoking in all workplaces. ${ }^{46}$ After only 10 weeks the court ruled the new board regulations null and void. ${ }^{47}$

In 2001, the board reintroduced the regulations, which prompted one last push by opponents to have the Capital Regional District Board consider having the Workers' Compensation Board regulations replace the bylaw. Opponents used the high costs of enforcement as a reason but the CHR's new CEO decided enforcement was a health issue and committed \$50 000 to the effort. With this financial backing, the board decided the bylaw would remain, without modifications. ${ }^{25}$

With the board's approval, the CHR served legal papers to 12 of the remaining non-compliant bars. Only two establishments decided to defend themselves in court $^{48}$ where they argued that the district bylaw was too broad and did not clearly instruct owners and operators on how to control smoking in their establishments. The British Columbia Supreme Court Justice responded by granting the district an injunction which set out very specifically what establishments should be expected to do to control smoking on their premises. ${ }^{49}$

\section{The tobacco industry's role}

Because of its lack of credibility the tobacco industry has a well established practice of staying in the shadows and working through front groups. ${ }^{1150}$ The tobacco industry encourages "accommodation," and ventilation solutions by recruiting local hospitality organisations or, when necessary, creating new ones. ${ }^{11}$ The tobacco industry's undisclosed role in recruiting the hospitality industry with the goal of rescinding the bylaw in Victoria is laid out in a 1998 memorandum of the Canadian Tobacco Manufacturers' Council (CTMC). ${ }^{24}$ The memo revealed that four "new" properties in the Victoria area had joined the Courtesy of Choice "accommodation" programme to counter smoking bylaws. ${ }^{51}$ The new establishments included the Red Lion Inn, Victoria Plaza, Westwind Plaza, and Don Rittaler's Sooke River Hotel. The memo also explained that after having discussed Rittaler's court challenge with him, "we are offering to provide media training and support for his upcoming interviews". ${ }^{24}$ The memo further outlined the strategies they were using to help the local hotels boost public awareness for a "choice and ventilation" solution and how they "stressed the importance of "strength in numbers" in order to counter the impending bylaw". ${ }^{24}$

Two other 1998 memos also showed that through the Courtesy of Choice programme, the CTMC funded a strategy to promote ventilation as a solution to smokefree bylaws. ${ }^{52}$ One of the memos from a council public relations consultant, Susan Walsh, to Matt Winokur, director of worldwide regulatory affairs at Philip Morris USA, outlined a meeting for "ventilation consultants working on the hospitality issue either directly or through programs such as Courtesy of Choice". ${ }^{53}$

Walsh also organised a meeting for those "helping to organize the fight against smoking bans in the hospitality sector". Some of the topics to be discussed included compliance and enforcement issues, economic impact, and a central 
resource centre on smoke bans for use by the opposition. ${ }^{53}$ People suggested to attend the meeting included: "Tobacco industry employees involved in the hospitality sector issue" and "Consultants working with the industry to fight smoke bans - particularly any regional consultants who may be an ongoing contact on their area".$^{53}$ The group included the Hotel Association of Canada, Rothmans, Benson and Hedges, RJR MacDonald Inc, Imperial Tobacco, Philip Morris , RJ Reynolds, Dasko Communications Group and individuals such as tobacco industry consultant John Luik, ${ }^{54}$ who travelled to Victoria to debate Stanwick on the proposed bylaw, and Tim Crowhurst, $^{45}$ a public relations consultant whose tobacco industry ties were exposed during his campaign against the Workers' Compensation Board regulations..$^{556}$

While we were unable to identify specific documentary evidence that the tobacco industry was orchestrating and financing The Age of Majority Business Coalition (aka Freedom of Choice Coalition), the pattern of opposition mirrored Clark's Lower Mainland Hospitality Group which was funded by the industry to oppose the Vancouver bylaws and received strategic advice from the CTMC. ${ }^{14}{ }^{57}$ One copy of a proposal on a smokefree bylaw to the Vancouver City Council by the Hospitality Group was found in the files of Philip Morris' Winokur, which had been circulated to tobacco interests in Vancouver, Ottawa, and Toronto. ${ }^{58}$ Lawyer Timothy Williamson, who represented Victoria's last two holdouts in court, ${ }^{40}$ also represented the British Columbia Liquor Licensee and Retailers Association, which had ties to the tobacco industry ${ }^{43}{ }^{44}$ when it challenged, and ultimately overturned, the Worker's Compensation Board smoking regulation. ${ }^{47} 59$

CCG Consulting Group, the Vancouver agency Bruce Clark hired to evaluate the financial impact of a smokefree bylaw, also prepared a similar report for the restaurant and hospitality industry in Toronto that predicted negative economic consequences, ${ }^{60}$ a prediction that did not materialise. ${ }^{61-63}$ In both reports, CCG obtained data from Insight Research Canada Ltd, an organisation that in 1995 also conducted a survey on Vancouver dining establishments on behalf of the Hospitality Group. This survey was located in previously secret Philip Morris tobacco documents. ${ }^{64}$

Since 1995 the CTMC has funded the Canadian Hotel Association of Canada $\$ 800000$ a year to run the Courtesy of Choice programme which mobilises the hospitality industry against smoking restrictions. ${ }^{51}$

\section{DISCUSSION}

The Capital Regional District smokefree restaurant and bar bylaw was successfully enacted and implemented because the health authorities took care to draft a strong law and took the enforcement seriously.

The fact that the health authorities were able to secure the cooperation of the district's local Food and Restaurant Association by taking its president, Monsour, to California to see that the law was working well there and enjoyed support from the California Restaurant Association, ${ }^{78}$ helped dispel the myth, perpetuated by the tobacco industry, that smokefree bylaws were bad for the hospitality business, and created an invaluable ally.

Three years after the bylaw went in to effect, an Ipsos Reid survey demonstrated that not a single type of entertainment venue experienced a decrease in patronage. ${ }^{20}$ In addition on behalf of the Workers' Compensation Board, Pacific Analytics, an independent organisation, was hired to analyse the economic effects of the Victoria bylaw. They concluded that there were no economic impacts. ${ }^{65}$

As in other localities, where the tobacco industry was working through intermediaries to encourage opposition to and non-compliance with the law, ${ }^{8}$ obtaining compliance from a small but vocal minority of bars and pubs became one of the toughest battles for the CHR. As in California, these limited

\section{What this paper adds}

Even though the tobacco industry mobilises opposition to smokefree policies by working through the hospitality industry in the USA, public health advocates have been able to overcome this opposition and enact and implement $100 \%$ smokefree policies. Despite differences in government structures and cultural traditions in Canada, the industry uses similar strategies as in the USA and the counter-strategies by health officials are the same. It is possible to overcome serious opposition orchestrated by the tobacco industry and develop and implement a 100\% smokefree bylaw in Canada. Doing so requires attention to detail in drafting the bylaw, as well as a public education campaign on the heath dangers of secondhand smoke and active enforcement to overcome organised resistance to the bylaw. Jurisdictions considering smokefree bylaws should anticipate this opposition when developing and implementing their bylaws.

compliance problems were widely publicised in the media. ${ }^{66}$ The CHR staff realised that they had naively thought that the bylaw was a health issue, and were not prepared for the defiant minority, but quickly recognised this fact and adapted their policies. In their consultation with Californians, they had been forewarned about some of the problems enforcement personnel faced but they chose to believe that because the district was a different region, with a different culture, these problems would not arise or would not be the same. ${ }^{13}$ They were wrong. The fact that the CHR staff realised this and moved decisively to enforce the law eventually eliminated these problems. It is important that any municipality proposing a smokefree bylaw plan active educational and enforcement campaigns to counter any orchestrated opposition that may develop. Since the great majority of establishments obey the law, a few strong enforcement actions bring everyone into compliance.

The health advocates chose to have one group, the District Tobacco Free Task Force, ${ }^{67}$ as one voice for all the proponents of the bylaw, with the large established health groups saying little other than promoting educational materials on the health effects of SHS. ${ }^{19}$ The large voluntary health groups, such as the Cancer Society, Heart and Stroke Foundation, and the Lung Association, have more public credibility and authority than an unknown coalition or task force. Some of the bylaw advocates in Victoria (and the organisations themselves) thought that keeping a low profile was a good strategy; however, the literature indicates that it is more effective when policy makers have different advocates who are recognised and have high credibility with the public, and continually reiterate the arguments for tobacco control and the science that supports it separately and in their own voices. ${ }^{68-71}$

\section{Conclusion}

Similar to other smokefree local ordinances in the USA and around the world, a $100 \%$ smokefree law was not simply proposed and implemented. ${ }^{1}$ Like groups in the USA with documented ties to the tobacco industry, ${ }^{11}{ }^{1250}$ local hospitality groups opposed the bylaw. By the time the district passed its bylaw in 1996 there had been over a 10 year process of progressively stronger bylaws (table 1), which set the groundwork for a strong, well written $100 \%$ smokefree bylaw. The success of the district in passing, implementing, and enforcing this bylaw was due to a small team of dedicated health professionals, lawyers, and politicians who created a strong educational campaign that countered tobacco industry strategies, and wrote strong bylaws and persevered when enforcement became difficult and contentious. The history of the Capital Regional District smoking bylaws illustrates how 
to succeed for other jurisdictions that are thinking of, or have started the movement toward, 100\% smokefree public places.

\section{ACKNOWLEDGEMENTS}

We thank Richard Stanwick and Dianne Stevenson for their thorough review of an earlier draft of the paper, and Cynthia Callard for her comments and assistance with locating tobacco industry documents. This work was supported by National Cancer Institute grants CA-61021 and CA-87472.

\section{Authors' affiliations}

J Drope, S Glantz, Center for Tobacco Control Research and Education, Institute for Health Policy Studies and Cardiovascular Research Institute, University of California, San Francisco, San Francisco, California, USA

\section{REFERENCES}

Balbach E, Glantz S. Tobacco wars: inside the California battles. Berkeley: University of California Press; 2000

2 Heironimus J. Impact of workplace restrictions on consumption and incidence. 1992 Philip Morris; 21 January 1992. Bates No. 2045447770/7806

3 Anon. A smokers' alliance: draft. Philip Morris. Bates No. 2025771934/1937

4 Fichtenberg C, Glantz S. Smokefree workplaces substantially reduce smoking: a systematic review. BM 2002;325:188-91.

5 Samuels B, Glantz S. The politics of local tobacco control. JAMA 1991;266:2110-17

6 Traynor M, Glantz S. New tobacco industry strategy to prevent local tobacco control. JAMA 1993:270:479-86.

7 Macdonald H, Glantz S. Political realities of statewide smoking legislation: the passage of California's Assembly Bill 13. Tobacco Control 1997;6:41-54.

8 Magzamen S, Glantz S. The new battleground: California's experience with smoke-free bars. Am J Public Health 2001;91:245-52.

9 Dearlove JV, Bialous SA, Glantz SA. Tobacco industry manipulation of the hospitality industry to maintain smoking in public places. Tobacco Control 2002;11:94-104.

10 Dearlove JV, Glantz SA. Boards of health as venues for clean indoor air policy making. Am J Public Health 2002;92:257-65.

11 Dearlove J, Aguinaga Bialous S, Glantz S. Tobacco industry manipulation of the hospitality industry to maintain smoking in public places. Tobacco Control 2002;11:94-104.

12 Ritch W, Begay M. Strange bedfellows: the history of collaboration between the Massachusetts Restaurant Association and the tobacco industry. Am J Public Health 2001;91:598-603.

13 Stevenson D. Interview with Jacqui Drope. 2001

14 Cunningham R. Smoke \& mirrors: the Canadian tobacco war. Ottawa: International Development Research Centre, 1996.

15 Bell J. Health committee puts smoking ban onto back burner. Victoria-Times Colonist 16 November 1995.

16 CCG Consulting Group Ltd. The hospitality sector and a Vancouver smoking ban. Vancouver, September 1995

17 Hirschfield R. Feasibility of ventilation and filtration to control cigarette smoke. Victoria: DW Thomson Consultants Ltd, 1 April 1996.

18 Stanwick R. Interview with Jacqui Drope. 2001

19 Stanwick R, Stevenson D, Boyd W. Interview with Jacqui Drope. 2002.

20 Reid I. 2001 Municipal Smoking Bylaw Survey. Capital Regional District; 30 July 2001

21 Monsour D. Interview with Jacqui Drope. 2001.

22 Munro H. Smoking ban won't be total. Vancouver Sun 1 February 1996.

23 McLintock B. Ban on smoking faces challenge in court. The Province 10 May 1998; Sect. A6.

24 Small D. Victoria update. 1998 Canadian Tobacco Manufacturer's Council; 2 June 1998. Guildford. Bates No. 2065254964

25 Stanwick R. Correspondence with Stan Glantz. 2002

26 McLintock B, Foden B. WCB: smokeless workplaces: All workers would be guaranteed smoke-free jobs in all of province. The Province 16 December 1998; Sect. A3

27 Anon. Parker Hospitality. The Cigarette Gazette 1998, p 4.

28 The Victoria Age of Majority Business Coalition. What does no smoking mean to your business. In: 1998

29 Thursdays Sports Bar. Freedom of choice is the issue, freedom of choice is the goal. no date.

30 Queenswood Consulting Ltd. Capital Regional District Clean Air Bylaw: implementation program. 23 August 2001

31 McLintock B. California bar owners bring news on smoking. The Province 29 October 1998.

32 McLintock B. Warning: cigarettes smoked here. The Province 3 January 1999, 3; Sect. A2

33 Hume M. Dying smokers may be left out. National Post 1999; Sect. A1

34 Drew M. Interview with Jacqui Drope. 2001.

35 Cleverly B. Leonard wins with ease. Victoria Times-Colonist 21 November 1999.
36 Stanwick R. Carcinogen has no place in public areas: a ventilation system for second-hand smoke makes as much sense as having peeing and non-peeing sections in swimming pools. Times Colonist 12 December 1998; Sect. A18.

37 Age of Majority Business Coalition. Businesses want right to freedom of choice. Times Colonist 12 December 1998; Sect. A18.

38 Doll \& Penny's Cafe Ltd. v. Vancouver (City). In: British Columbia Court of Appeal; 2000

39 McLintock B. Barmen vow to spook tourists. The Province 19 January 1999.

40 McDannold G. Interview with Jacqui Drope. 2001

41 Westad K. Pub gives in on smoking, agrees to fine. Victoria Times-Colonist 15 February 2001

42 Anon. Bar owners facing smoking ban worry over loss of business. Times-Colonist 2 January 2000, 2; Sect. C2.

43 Liquor Licensee and Retailers Association. Thanks to these valued sponsors for making the LLRA convention a success. Publican 2001; Winter:28.

44 Liquor Licensee and Retailers Association. Associate members Publican 2001; Spring:28.

45 AIRSPACE, Action on Smoking and Health. Breathers' Digest. In: The Tobacco Industry funds "hospitality" organizations. Burnaby, BC

46 McCune S. Pubs taking ban to court. The Province 27 January 2000; Sect. A3

47 Clark G, Lazaruk S, Bermingham J. Ban goes up in smoke. The Province 23 March 2000; Sect. A2.

48 Anon. Two bars still hold out against smoking ban. Victoria-Times Colonist 22 June 2001.

49 Judgement of Justice Allen Melvin, B.C. Supreme Court, in the case of Sooke River Hotel Ltd. and Donald Rittaler, and CRD vs. Jadwiga Holdings and Great Dane Enterprises Ltd, carrying on business as Tudor House, and Michael Holmes. In: B.C. Supreme Court; 2001.

50 Samuels B, Glantz S. The politics of local tobacco control. JAMA 1991;266:2110-17.

51 Courtesy of Choice. Courtesy of Choice Facts. 1998 Philip Morris; 6 March 1998. Bates No. 2065255096. URL: http:// legacy.library.ucsf.edu/tid/vpy77d00

52 Small D. Ventilation alternative to smoking bans. Philip Morris, 1998 Bates No. 2065255097. URL: http://legacy.library.ucsf.edu/tid/ wpy $77 \mathrm{~d} 00$

53 Walsh S. June 22 meeting on smoke bans. 1998; 3 June 1998. Bates No. 2065254984. URL: http://legacy.library.ucsf.edu/tid/doy77d00.

54 Drope J, Chapman S. Tobacco industry efforts at discrediting scientific knowledge of environmental tobacco smoke: a review of interna documents. J Epidemiol Community Health 2001;55:588-94.

55 Anon. Contact List: Evaluating strategies in respect to public smoking initiatives. 1998 Philip Morris; June 1998. Bates No. 20652549934994. URL: http://legacy.library.ucsf.edu/tid/joy77d00.

56 Anon. Agenda: Evaluating strategies in response to public smoking initiatives: Holiday Inn Select, Toronto Airport 970 Dixon Road, Etobicoke Roof Garden, 12th floor 980622 9:30 A.M. - 12:30 P.M 1998 Philip Morris; 22 June 1998. Bates No. 2065254992. URL: http://legacy.library.ucsf.edu/tid/ioy77d00.

57 CBC. Early Edition Rick Cluff (Host): Rob Cunningham (Canadian Cance Society). In: 2000

58 Lower Mainland Hospitality Industry Group. How we can assure clean indoor air - without destroying businesses and jobs. 1995 Philip Morris; 26 September 1995. Bates No. 2046287293. URL: http://legacy.library ucsf.edu/tid/feq57d00.

59 Morton B. WCB fail to consult on smoking ban, group argues: a lawye for liquor retailers and licensees says a critical change was made to the regulations after hearings. Vancouver Sun 14 March 2000; Sect. B 1.

60 CCG Consulting Group Ltd. The food services and hospitality sector and a Metro Toronto smoking ban: an analysis of economic consequences. Vancouver, BC; 1996.

61 Glantz S, Smith L. The effect of ordinances requiring smoke-free restaurants on restaurant sales. Am J Public Health 1994;84:1081-5.

62 Glantz S. Smoke-free restaurant ordinances do not affect restaurant business. Period. Journal of Public Health Management and Practice 1999:5(1):vi-ix.

63 Scollo M, Lal A, Hyland A, et al. Why studies of the economic effects of smoke-free policies on the hospitality industry reach different conclusions. Tobacco Control 2003;12:13-20.

64 Insight Canada Research. Vancouver Dining Establishment Survey 1995 Philip Morris; October 1995. Bates No. 2046287327/7347.

65 Pacific Analytics Inc. The economic impacts of the proposed amendment to the ETS regulation. Victoria: Workers Compensation Board of British Columbia, 2001

66 Magzamen S, Charlesworth A, Glantz S. Print media coverage of California's smokefree bar law. Tobacco Control 2001;10:154-60.

7 Cull E. Interview with Jacqui Drope. 2001.

68 Kingdon JW. Agendas, alternatives, and public policies. Boston: Little Brown; 1984

69 Sabatier P, Jenkins-Smith HC. Policy change and learning: an advocacy coalition approach. Boulder, Colorado: Westview Press; 1993.

70 Montini T, Bero L. Policy makers' perspectives on tobacco control advocates' roles in regulation development. Tobacco Control $2001 ; 10: 218-24$

71 Bero L, Montini T, Bryan-Jones K, et al. Science in regulatory policy making; case studies in the development of workplace smoking restrictions. Tobacco Control 2001;10:329-36. 